\title{
LETTER
}

\section{Additional bad news from regulatory T cells in sepsis}

\author{
Guillaume Monneret* and Fabienne Venet \\ See related commentary by Christaki and Patrozou, http://ccforum.com/content/14/2/132
}

We would like to revisit the commentary by Christaki and Patrozou [1] on regulatory T cells (Tregs) as significant modulators of various immune responses after severe injury. Indeed, we would like to add some very recent references that strongly reinforce their results.

Strong evidence indicates that, in septic conditions, increases in Tregs have deleterious consequences. In septic shock patients, augmented levels of Tregs significantly and inversely correlated with decreased lymphocyte proliferation [2]. This phenomenon, recapitulated after cecal ligation and puncture (CLP) in mice, was totally abrogated by using Foxp 3 small interfering RNA (Foxp3 is a specific Treg transcription factor). In a similar model [3], after mild CLP, mice presented with immunosuppression that dampened defenses against secondary infectious challenge (Legionella pneumophilia inoculation 15 days after CLP). The restoration of efficient responses against infection was achieved thanks to anti-glucocorticoid-induced TNF receptor antibodies, known to abrogate Treg-mediated suppression. Lastly, a recent paper published in Blood [4] reported that sepsisinduced immunosuppression resulted in a reduced immune tolerance that facilitated the rapid growth of solid tumors. Foxp3+ Tregs were responsible for this effect. Although tumors were subcutaneously implanted (which is not relevant to septic patients), this indicates the occurrence of a major immunosuppressive state induced by sepsis and driven by Tregs in this model.
Collectively, and beyond Tregs (unfortunately not the sole bad guys in the game), these data highlight the profound impact of sepsis/injury on immune functions. This should stimulate basic research and development of innovative therapies for rebalancing immune homeostasis in severe critical illness.

\section{Abbreviations}

$C L P$, cecal ligation and puncture; Treg, regulatory T cell.

Competing interests

The authors declare that they have no competing interests.

Published: 20 December 2010

References

1. Christaki E, Patrozou E: The kinetics of T regulatory cells in shock: beyond sepsis. Crit Care 2010, 14:132.

2. Venet F, Chung CS, Kherouf H, Geeraert A, Malcus C, Poitevin F, Bohé J, Lepape A, Ayala A, Monneret G: Increased circulating regulatory T cells $(\mathrm{CD} 4(+) \mathrm{CD} 25(+) \mathrm{CD} 127(-))$ contribute to lymphocyte anergy in septic shock patients. Intensive Care Med 2009, 35:678-686.

3. Nascimento DC, Alves-Filho JC, Sônego F, Fukada SY, Pereira MS, Benjamim C, Zamboni DS, Silva JS, Cunha FQ: Role of regulatory T cells in long-term immune dysfunction associated with severe sepsis. Crit Care Med 2010, 38:1718-1725.

4. Cavassani KA, Carson WF 4th, Moreira AP, Wen H, Schaller MA, Ishii M, Lindell DM, Dou Y, Lukacs NW, Keshamouni VG, Hogaboam CM, Kunkel SL: The post sepsis-induced expansion and enhanced function of regulatory $T$ cells create an environment to potentiate tumor growth. Blood 2010, 115:4403-4411.

doi:10.1186/cc9357

Cite this article as: Monneret $G$, Venet F: Additional bad news from regulatory T cells in sepsis. Critical Care 2010, 14:453.
*Correspondence: guillaume.monneret@chu-lyon.fr

Hospices Civils de Lyon, Hôpital E Herriot, Immunology Laboratory, 69437 Lyon Cedex 03, France

\section{C) Biomed Central}

c 2010 BioMed Central Ltd 